\title{
The 12th International Geological Congress, Toronto, 1913
}

\author{
School of Geography and Earth Sciences, McMaster University, Hamilton ON L8S 4K1 Canada, Email: middleto@mcmaster.ca
}

Canada made its first bid for the 1906 IGC, but was successful seven years later. As it happened, this was a lucky chance because in the intervening years the economy had improved, due in part to the discovery of new mineral resources and the development of hydroelectric power in Ontario. The Geological Survey of Canada had been reorganized, and Provincial Departments of Mines were established in Ontario and Quebec. Research and graduate studies had developed in the three leading universities (McGill, Toronto and Queen's). The older generation of Canadian geologists had been concerned mainly to explore and map the immense Canadian land-mass, but by 1910 a new generation, well trained in German and American graduate schools, had begun to participate in developing new ideas, particularly about Precambrian and glacial geology. The sessions on these topics were the most successful at the Congress; but the transcontinental excursions, run with the active assistance of the railway companies, were outstanding. The Guide Books published by the GSC were the best summary of Canadian geology then available, and probably this IGC's most enduring contribution to geological science. A summary of the geological issues encountered in the course of the important Excursion A2 is provided by Michael Easton.

\section{Introduction}

In 1903, Robert Bell, then Acting Director of the Geological Survey of Canada (GSC) travelled to the Vienna IGC to invite the delegates to accept Canada as the site for the 1906 Congress. Though Bell had a financial commitment from the Canadian Government, it did not come close to the commitment of some $\$ 300,000$ that supported the rival bid by the Mexican delegates. In retrospect, this was probably a good outcome both for Canada and for the IGC. Canada made no serious bid for 1910 and the IGC met in Stockholm; but when that meeting took place, Canada sent a strong delegation, consisting of Frank D. Adams, Arthur P. Coleman, and Willett G. Miller (see below for biographies). These men represented a new generation of well-trained professional geologists. Each of them had recently made notable contributions to science, and had departed significantly from the "inventory science" that had largely characterized earlier geological work in Canada (Zeller, 1987: 269-274) and elsewhere. Moreover, Canada had itself been transformed by the economic prosperity of the previous ten years.

The organization of Canadian geology was, and to some extent still is, an anomaly among the developed nations. In 1842, William Logan was appointed Provincial Geologist for Canada, which at that time included only Ontario and Quebec. Even after the 1867 Confederation, there were still no national non-government organi- zations promoting the sciences until the founding of the Royal Society of Canada (RSC) in 1882. By that time, the influence of the GSC (and of McGill under its Principal John William Dawson) had grown to the point where geologists dominated among the scientific community; with the result that the RSC's Transactions became the preferred publication medium for geology, other than the publications of the GSC itself, and American journals, such as the American Journal of Science. This dominance continued for many years, and perhaps contributed to the relatively weak development of advanced geological studies in the universities, and to the absence of any national geological society until the founding of the Geological Association of Canada in 1947. Nevertheless, by the beginning of the twentieth century things had begun to change. The mining industry had become a major part of the economy, with its own professional organizations (Canadian Mining Institute, 1898) and publications (CMI Journal, 1906; Canadian Mining Review, 1882). The Departments of Mines, set up by the Provincial governments began to rival the monopoly previously enjoyed by the GSC. In the universities, McGill, Toronto, and Queen's had developed strong undergraduate programs, and began to award the first $\mathrm{PhDs}$ in geology (1900 at Toronto; 1910 at McGill).

By 1913, Ontario was by far the most populous part of Canada and the Province with the greatest economic growth. Though it had been settled only since the beginning of the nineteenth century, half of its population now lived in cities and the industrial sector was growing rapidly. This was due in part to the development of hydroelectric power at Niagara Falls, beginning with the creation of the Ontario Hydroelectric Power Commission in 1906. Before this, Ontario (and Quebec too) had been short of industrial power, because of the absence of local coal resources. The mining industry was also thriving: Sudbury nickel had been exploited since 1887 and INCO was founded in 1902; silver was discovered at Cobalt in 1903; and gold at Porcupine Lake in 1909 and at Red Lake in 1912. Toronto was rapidly overtaking Montreal as Canada's business centre. It was well connected by rail, by far the most convenient form of travel in the early twentieth century, and was conveniently close to some major geological attractions (Niagara Falls and Quaternary glacial features; Sudbury and the classic Huronian, with its Precambrian glacial deposits; the Grenville of the Haliburton-Bancroft area: see below).

The GSC had moved from Montreal to Ottawa in 1881; the Ontario Bureau of Mines was established in 1891; and the Ontario School of Mining and Agriculture was established in 1893 and soon incorporated into Queen's University. Earlier, significant scientific meetings had been held in Montreal (AAAS, 1882; BAAS 1884) but by 1897 Toronto had hosted its first two major meeting (AAAS, 1889; BAAS, 1897). The Royal Ontario Museum, affiliated with the university, was constructing a new building in Toronto that would house both the Museum of Mineralogy (Director T. L. Walker) and the Museum of Paleontology (Director W. A. Parks, who had earned the first $\mathrm{PhD}$ in geology granted by the University of Toronto). So the logical choice of a city to host the IGC was Toronto, not Montreal or Ottawa. To recognize the importance of these two cities in Canada's geological community, however, receptions were also held there, before the Congress began. The ceremonies included the unveiling at the GSC Headquarters in Ottawa of a plaque dedicated to Sir William Logan (Compte-Rendu: 170; Zaslow 1975: 303). 


\section{The state of geological science in the world}

At the end of the nineteenth century, geology as a profession was well established in state surveys and universities: several colleges catered specifically to training geologists for the mining industry. Although there were large discoveries of oil in the first decade of the twentieth century, it was not until the second and third decades that the petroleum industry became a major employer of geologists in the United States: in the first decade, geologists were involved, but not yet hired on staff by petroleum companies. The Toronto CompteRendu gave a rather complete list of geological societies, geological surveys, and mining societies, but no groups representing the petroleum industry, for the good reason that such groups did not yet exist. The American Association of Petroleum Geologists was not founded until 1917. The main fuel of geological interest in 1913 remained coal, which was the subject of a three-volume compilation in Toronto that had been planned almost ten years earlier.

A number of major geological syntheses had recently been published in regional geology and tectonics (Suess), geomorphology (Davis), petrology (Rosenbusch, Iddings, Van Hise, the CIPW classification), and geochemistry (Washington, Clarke). The Carnegie Institute was founded in 1902, and its Geophysical Institute-soon to become the world's leading centre for experimental petrology and geochemistry - was established in 1906. Major studies within Precambrian shield areas had already been carried out (e.g., Sederholm, who also introduced the concept of "migmatites" in Scandinavia; or Lapworth, Peach and Horne's work in north-west Scotland).

The discovery of radioactivity late in the previous century provided an internal heat source to drive the earth's heat engine, and freed the earth sciences from the constraints of a 100 Ma history, imposed by Kelvin's thermodynamic arguments. The earliest absolute age dates, using still crude radioactive techniques, showed that the earth was probably an order of magnitude older than Kelvin believed (Boltwood, Strutt, Holmes; see Lewis, 2000). The fossil record had been extended back to the beginning of the Cambrian, and major discoveries of dinosaurs and other large vertebrates made both in the USA and in Canada (1884 by J. B. Tyrrell) though collecting in Canada lagged behind that in the USA. There had even been some reports of Precambrian fossils (e.g., by C. D. Walcott in 1899, reported at the Paris IGC in 1901). In Canada sceptics still remembered the fate of Eozoon canadensis (discredited as a valid fossil by 1900 , though in part revived much later as an early stromatolite; Hofmann, 1982).

Extraterrestrial studies took a major step forward with the proof of the meteoric origin of the Arizona crater (Barringer, Merrill), and the development of the "planetesimal" hypothesis for the origin of the solar system (Chamberlin). Seismology, begun in the previous century, began to organize networks of observatories, recognized the existence of the earth's core, and that a seismic discontinuity (the Moho) separated the crust from the earth's denser mantle. In 1906, the USA had suffered its first major destructive earthquake at San Francisco, which led almost immediately to the founding of the Seismological Society of America, and the formulation of the elastic rebound theory of earthquakes. Isostasy, proposed in the previous century, gained important support from gravity studies, and began to be taken seriously by geologists (it soon became a major support for a mobilist view of the earth). The first steps were taken towards establishing the science of paleomagnetism, though the importance of this for geology was not recognized until the 1950s.

It was recognized that the Pleistocene ice age was a relatively long, complex event involving perhaps four major ice-sheet advances, and that there had been other glaciations much earlier in earth history.

Thus it is hard to imagine any period, after the golden age of geology at the beginning of the nineteenth century and before the flowering of plate tectonics in the 1960s, when the geological sciences were in a more active and fruitful state.

To what extent had Canadian geologists participated in these events? And how were they reflected in the programs organized for the Toronto IGC? Both questions can be answered by examining first, the Organizing Committee itself, and then the list of keynote speakers who were invited to address the Congress.

\section{The Organizing Committee}

The President was Frank Dawson Adams (see Figure 1). Born in Montreal in 1859, he had been educated at McGill, Yale and Heidelberg. His doctoral thesis, supervised by the German petrographer Harry Rosenbusch, was on the anorthosites in the Laurentians, north of Montreal. Adams showed that, far from being metamorphosed sediments, part of Logan's "fundamental gneiss," they were intrusive rocks. His first professional appointment had been as a "chemist" with the GSC but he resigned in 1889 to teach at McGill. In 1891, with GSC assistance he began to work on the Grenville rocks of Ontario and in 1910, with Alfred Barlow, he had just published his GSC Memoir "Geology of the Haliburton and Bancroft areas, Province of Ontario" perhaps the most scientifically influential of all the GSC Memoirs published since the first one (Logan's "Geology of Canada"). Since 1897 Adams had been engaged in a pioneer experimental study of the physical behaviour of rocks under high pressure-studies carried out more than ten years before similar studies began at the Carnegie Laboratory and Harvard. He had been elected FRS in 1907. At the time of the IGC he was President of the Royal Society of Canada and Dean of Science at McGill.

The Secretary General was the Director of the GSC, Reginald Walter Brock (see Figure 1). He was born in Ontario in 1874, educated at Toronto and Queen's, and spent two years studying with Rosenbusch at Heidelberg, but without completing a doctorate. He worked short periods with the GSC, and then taught at Queen's until he was appointed GSC Director in 1907 at the age of 34. This ended a period of political uncertainty and turmoil, both administrative and

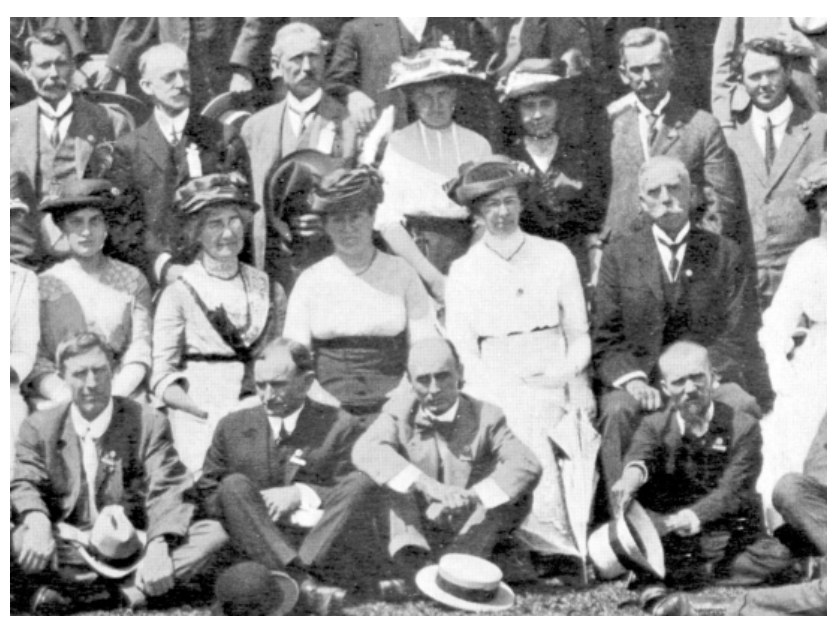

Figure 1 Part of the panoramic photograph taken, 13 August, in front of the University of Toronto [see Figure 2], and published in the Compte-Rendu. It included some 290 registrants (almost all of whom were identified). This small selection includes: $F$. D. Adams (centre right), and $R$. W. Brock (seated, left). Seated to the right of Brock are E. S. Moore (Pennsylvania State University, USA), T. M. Hills (Ohio State University, USA) and H. Bäckström (University of Stockholm, Sweden). Standing in the third row are: D. R. Keys (University of Toronto), W. F. Ferrier (mining geologist, Toronto), J. McEvoy (mining geologist, Toronto), two ladies, C. Schuchert (Yale University, USA) and P. E. Raymond (Harvard University, USA). 


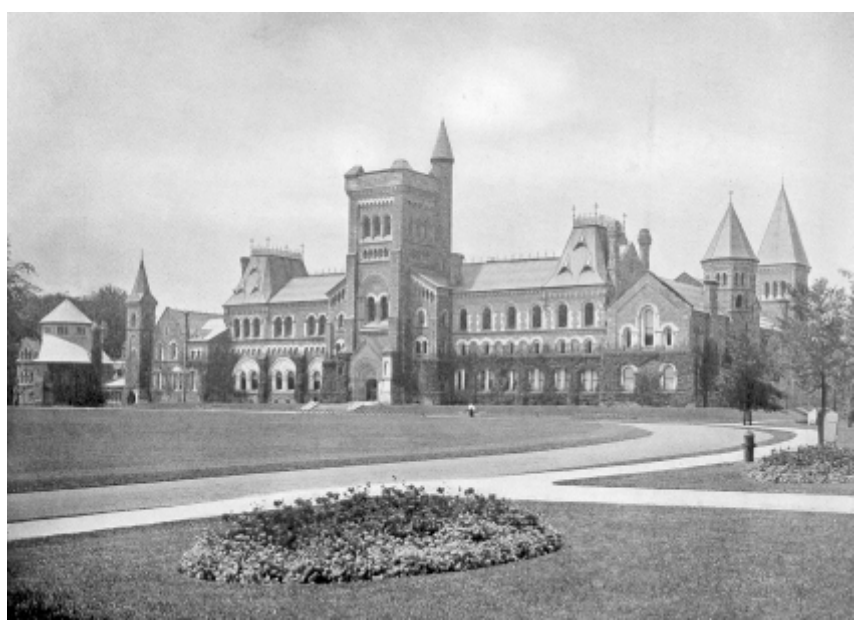

Figure 2 The Main Building at University of Toronto, as it was in 1913 [Langton et al., 1906, p. 57]. Many Congress events were held in this building. It was built in 1858, of sandstone imported from Ohio, and reconstructed after a fire in 1890 destroyed much of the east wing (to the right in the photo). It has been described, perhaps overenthusiastically, as "the crowning glory of architecture in Toronto ... perhaps the finest building in Canada."

scientific, at the GSC, that had started with the early death of George Dawson in 1901, continued during the Acting Directorship of Robert Bell, and culminated with the brief reign of Albert P. Low, who was appointed Director in 1906 but almost immediately fell seriously ill. Finally, with the active support of the new Liberal Government, reorganization was completed and the GSC moved into a new building in Ottawa in 1911. Several well-qualified young geologists were appointed and the GSC was able to begin another fruitful period of scientific activity.

The Organizing Committee also included two more employees of the GSC: O. E. LeRoy, a draftsman and geologist ( IGC activities included the preparation of 140 new maps); and William McInnes, a geologist from New Brunswick, who had also worked in western Ontario and Manitoba (he handled much of the IGC editorial work and later became Director of the Victoria Museum). Willett G. Miller represented the Ontario Bureau of Mines: he had been trained at Toronto, and was appointed in 1893 as the first head of the Queen's School of Mining (when he took summers off to study at Harvard, Heidelberg and Chicago). His research included pioneer work on the use of x-rays for the identification of minerals. In 1902 he was appointed the first "Provincial Geologist" by the Ontario Government. Théophile C. Denis, born in France, educated at McGill, had worked for the GSC and in 1910 was appointed Superintendent of Mines for the Province of Quebec.

There were two University of Toronto members. Arthur P. Coleman was born in Quebec in 1852, educated at Victoria College (at that time an independent Methodist university, later a part of the University of Toronto) and at Breslau, where he obtain his doctorate in geology in 1881. Returning to Canada, he taught at Victoria (where he inspired R. A. Daly to become a geologist). After Victoria moved to Toronto to become part of the University, he became Professor of Geology (1901). By 1913, Coleman's studies of mineral deposits and glacial phenomena had made him one of the best known geologists in Canada. In 1910 he was elected FRS, and awarded the Murchison Medal of the Geological Society of London. William A. Parks, born in Hamilton, Ontario, in 1868 was educated at the University of Toronto, where he joined the teaching staff in 1893 and obtained his doctorate in 1900. In 1913, he was best known for his studies of stromatoporoids and the first volume of his comprehensive, five-volume work on the Building and Ornamental Stones of Canada; and he had just been appointed Director of the Museum of
Paleontology, which was one part of the Royal Ontario Museum. In later life he was instrumental in building up the Museum's fine collection of dinosaurs.

Two members of the Committee represented the mining industry. Joseph B. Tyrrell, born in Weston, Ontario, in 1858, was trained at the University of Toronto, and then joined the GSC. He spent several years working in western Canada and made a name for himself as an intrepid explorer of the Barren Lands, and as a strong advocate of the ice sheet theory of glaciation. After working in the Yukon he resigned from the GSC in 1898 so that he could return as a mining consultant. In 1906, he sold his Klondike interests, and returned to Toronto where he continued to work in the mining industry. $\mathrm{He}$ became one of Canada's best known geologists, and the subject of several book-length biographies. G. G.S. Lindsey was a grandson of William Lyon Mackenzie, a political journalist who led the brief rebellion of 1837 in Ontario. Lindsey was a lawyer (KC), active in Liberal politics, and had been general manager of the Crows Nest Pass Coal Company (in British Columbia). Since 1909, he had established his own practice in Toronto with clients in the mining community. Later Alfred E. Barlow was added to the Committee. He was born in Montreal in 1861, trained at McGill, and joined the GSC in 1883, working at first in the Sudbury area, later around Lake Temiskaming, and in Haliburton with F. D. Adams. He resigned from the GSC in 1907 to practise as a consultant geologist in Montreal.

In summary: the Committee included a fair representation of some of the best Canadian talent, with an emphasis on Precambrian and mining geology. Several of the Congress activists had been trained in Germany, as well as in Canadian and US universities (Middleton, 2005). It should be noted that although the RSC was not formally represented on the Organizing Committee, many Fellows played an active role in the Congress organization.

\section{The main themes and keynote speakers}

The formal Congress sessions were held at the University of Toronto, beginning with a "reunion" and welcoming speeches on the evening of Wednesday, 6 August, and ended with a garden party on the evening of Thursday, 14 August. On 7 August, most of the day was taken up with speeches, followed at 3 p.m. by the presentation of the three-volume publication on Coal Resources of the World. In the evening, Emmanuel de Margerie, President of the Geological Society of France, delivered a "popular lecture" on the Geological Map of the World, which he had been invited to give (to his chagrin) in English! In the remaining sessions, the speakers were free to choose one of the three official languages (French, English and German). The Compte-Rendu was published in French (except for the speakers' texts) and the Guide Books were published in English.

On most of the working days there were meetings of IUGS Commissions, and several "general" or "special" sessions. Sunday was a day of rest, thanks to the influence of the Lord's Day Observance Society in Toronto. There were also short excursions each week day, and 12 August was devoted entirely to three local excursions (to Niagara; to the Silurian of the Credit River, northwest of Toronto; and to the Pleistocene of the Scarborough bluffs, just east of the city). Each day, the City of Toronto made automobiles (presumably with chauffeurs) available for delegates who wished to explore the city. The city also produced a fine book, Toronto of Today, lavishly illustrated with pictures of Toronto's finest buildings (e.g., Figure 2), which was distributed to delegates. It is now available, unabridged at: http://www.archive.org/details/torontooftoday00igcuoft and make very interesting reading, particularly for those familiar with the modern city. Several days concluded with a reception: on 9 August, a garden party at David Dunlop's house in Rosedale; on 11 August, at the Town Hall; on 13 August, a banquet at the Arsenal on University Avenue. 
Two special sessions were held on the afternoon of 8 August. The first on Differentiation of Igneous Magmas included papers by R. A. Daly, Alfred Harker, Joseph Iddings, Henry Washington, and William Hobbs. There was no consensus about the mechanism of differentiation but a common theme was the use of graphical plots of chemical analyses. Hobbs' paper even compared chemical variation in igneous rocks with that in pelites. No doubt N. L. Bowen, who was present, but confined himself to one brief comment, was interested. He had just completed his PhD at MIT, where he had been a student of R. A. Daly, and had published the first of his well-known papers ("The order of crystalization in igneous rocks"). He had also begun the experimental studies that would revolutionize the whole approach to this topic, and make obsolete many of the hypotheses used by the speakers at this session (Yoder, 1992; Young, 1998). Those attending the session well knew about the research that was just beginning at the Carnegie Institute and as remarked by Bäckström of Sweden hoped that "some future Chairman in three to six years from now will call on Dr Arthur L. Day [present at the Congress] to give us his opinion regarding these problems."

The second session that afternoon was on Interglacial Periods, and the speakers were G. W. Lamplugh, A. P. Coleman, G. F. Wright, Warren Upham, W. Wolff, and W. C. Alden. The interested audience included Frank Leverett and Frank B. Taylor, who were about to publish their massive synthesis on the The Pleistocene of Indiana and Michigan and the History of the Great Lakes (USGS Monograph 53, 1915) which was to dwarf earlier syntheses (e.g., by J. W. Spencer) and stand as a monument until the development of Carbon-14 dating in 1949. Most speakers in 1913 tended to overestimate the time since the recession of the last ice sheet from southern Ontario, but to underestimate the duration and complexity of the Pleistocene glaciations. The Scarborough interglacial deposits were of great interest to those attending this session, and for some years after had a major influence on American ideas about interglacials, which has not been entirely justified by later studies. Almost nothing was heard in this session about the use of varves for "absolute" dating, perhaps because the topic had been prominent at the previous IGC in Stockholm.

On 9 August, there were two sessions in the morning: the most important being on the Characteristics of Paleozoic Seas, with papers by T. C. Chamberlin, Gustav Steinmann, Charles Schuchert, F. Frech, and Olaf Holtedahl. Chamberlin related changes in the shelf seas to tectonics ("diastrophism"). In retrospect, his ideas (made more familiar by his popular textbooks) seem to be distantly related to the now popular "Sequence Stratigraphy," but without there being any direct historic connection. Schuchert, too, was struck by the cyclicity of the stratigraphic record, which he approached from a paleogeographic point of view. Strangely he continued to accept what now seems a very short time scale, e.g., only 12 Ma for the whole of the Paleozoic. This session continued later the same day with two papers, one by E. O. Ulrich, on the "Ordovician-Silurian boundary," and the other by the two Chamberlins (T. C. and R. T) on "Periodicity of Paleozoic movements." Ulrich supported the idea of simultaneous, world-wide transgressions and regressions, with the major faunal breaks corresponding to the physical ones (a view which took little account of lateral facies changes: indeed the term "facies" was scarcely mentioned at the Toronto IGC). Joseph Barrell, though a registered member, did not attend the IGC sessions, Johannes Walther registered but did not attend, and A.W. Grabau neither registered nor attended, so the discussion was brief. The main afternoon session, on economic and chemical geology attracted little attention.

On 11 August the main sessions were held in the afternoon, and included a symposium on The Influence of Depth on Ore Deposits and included papers by J. F. Kemp, W. H. Emmons, and L. L. Fermor. The other sessions included a great variety of topics.

On 13 August there was a symposium in the morning on The Origin and Importance of Precambrian Sediments, with two papers by J. J. Sederholm, and others by G. A. J. Cole, John Horne, W. S.
Bayley, G. F. Matthew and C. K. Leith. This was a topic of considerable interest at the time, because of the realization that many Precambrian rocks, though now highly metamorphosed had once been sedimentary, and because of the hope, reiterated in the afternoon session on the stratigraphic subdivision of the Precambrian, that unconformities and distinctive lithologies could be used for that purpose. The other morning session was a continuation of the symposium on interglacials, and included presentations by H. L. Fairchild, Warren Upham, and J. B. Tyrrell. The afternoon session on Subdivisions of the Precambrian was one of the most lively of the Congress, and included papers by A. Strahan (largely on the Scottish highlands), A. C. Lawson, J. J. Sederholm, Sir T. H. Holland (on the Indian shield), A. P. Coleman (on Sudbury), C. K. Leith (on the Lake Superior region), W. H. Collins (on the Georgian Bay region, east of Lake Superior), and two papers by A. Lacroix (on Madagascar). Most speakers resisted attempts, notably by Lawson, to draw up a "standard stratigraphy," even for the southern part of the Canadian Shield. In the discussion, T. C. Chamberlin spoke in favour of distinguishing the Proterozoic, which he claimed was characterized by rocks such as quartzites and limestones, that could only be formed by long chemical weathering, from the "Archeozoic" (Archean of modern usage) which lacked such rocks, largely (in his view) because of the absence of land vegetation. Of course, in 1913, there was no evidence of land vegetation (and still few recorded stromatolites) in the Proterozoic. A. E. Barlow added a few derogatory remarks about the people who sat on committees charged with resolving stratigraphic disputes. In his view they consisted of "men of so-called judicial mind, [who have] no 'mind' at all and are most concerned in trying to reach some compromise decision. Truth will not admit of compromise."

That ended the main technical sessions. Clearly, papers dealing with Precambrian and Pleistocene studies were of the greatest interest to those attending this Congress, but they concentrated mainly on attempted stratigraphic correlations, which strike the modern geologist as premature and indeed futile, except within strictly limited areas. Use of way-up criteria, which might have helped resolve some stratigraphic problems, was not mentioned (though it was already well known to Leith). The session on petrology dealt mainly with studies on differentiation, using chemical analyses of rocks, but lacked any discussion of the use of the phase rule which had been proposed by V. M. Goldschmidt in 1911 (he did not subscribe to or attend the Congress).

To a modern observer, it seems strange that this IGC ignored geophysical topics, and took no notice of the future potential of radioactive dating. By coincidence, Arthur Holmes' book The Age of the Earth was published in 1913. The reviewer for Nature (J. P., in the 5 June, 1913, issue) took Holmes to task for having suggested that the oldest sediments were at least 1,300 Ma old! This was a notuncommon reaction, even among geologists, as many had become reconciled with an age of at most a few hundred million years (Lewis, 2000). In Canada, the Dominion Observatory had been set up in 1905, and from the beginning concerned itself with seismology, gravity and terrestrial magnetism, but it was not an official sponsor of the IGC, and none of its officers attended.

Not much attention was given to the increasingly well-known paleontological record, and no mention was made of the discovery of the Burgess Shale soft-body Cambrian fauna, discovered in the Canadian Rockies by Walcott in 1909. Walcott subscribed to the Congress, but did not attend the sessions. He did, however, meet the participants in Excursion C1 at Field, British Columbia, and gave an address to them in the evening. The participants had an opportunity to collect Cambrian fossils, but not at Walcott's Burgess Shale quarry, except for one (Rothpletz) who deserted from the Excursion (Yochelson, 2001: 125).

Just before the Congress, two publications appeared on Continental Drift (Wegener, 1912; Taylor, 1910). They would now be mentioned in almost any history of geology, however brief; but had they been known to the delegates they would no doubt have been 
dismissed as wild, unfounded speculations. It is an interesting irony, that Taylor's fine work (with Leverett) on proglacial precursors to the Great Lakes, which was given attention on field excursions, if not in the technical sessions, is now often ignored in favour of his paper on continental drift, which was indeed a highly speculative contribution.

By a strange coincidence, the next IGC in Canada was held in Montreal in 1972, only a few years after the "invention" of Plate Tectonics. Plate tectonics, though largely developed by geophysicists, was much more acceptable to geologists than continental drift ever was; and indeed there was a session on it in Montreal. But none of the plate-tectonic pioneers delivered papers there, not even the leading Canadian advocates, such as Tuzo Wilson (who organized the Tectonics sessions), Ward Neale, or Harold Williams.

\section{The field excursions}

In the late nineteenth and early twentieth century, most geologists would probably have agreed that although the technical sessions formed an essential part of the IGCs, the real benefits came from attending the field excursions. As a later IGC President (H. H. Read) famously remarked: "The best geologist is the one who has seen the most rocks." Geology was, and to some extent remains, a regional science, and for a geologist visiting an unfamiliar terrain, there is no substitute to being guided by another geologist who has expert local knowledge. Travel was slow and difficult in many parts of the world, even after the development of railroads. Not a few geologists, therefore, and particular those with university appointments, were prepared to devote a large part of the summer to travel to a region that related to their own professional interests. Even then, however, attending the field excursions was a luxury that many geologists could not afford.

In Toronto, there were 981 "members" (who received the publications). They representing forty-nine countries, but fewer than half (467) actually attended. The Organizing Committee clearly recognized that the excursions were "the most important part of the Congress" (Compte-Rendu, p. vii) and organized twenty-seven excursions, travelling a total of 25,000 miles. Though most of them (twenty-two) were confined to Ontario and Quebec (together already a large area), five ranged from the Atlantic region (A1, before the Congress) to the Pacific coast, including, after the Congress, two transcontinental railway trips (C1 and $\mathrm{C} 2$ ) and two trips (C8 and C9) in British Columbia and the Yukon. The most popular excursions were the longest. A1, led by G. A. Young, J. M. Clarke and E. R. Faribault had eighty-eight registrants. C1, led by F. D. Adams and J. B. Tyrrell, and eighteen other guides, had ninety-eight registrants, of whom some fiftyeight returned by the eastbound train. $\mathrm{C} 2$, led by R. W. Brock and J. McEvoy, with twenty-one other guides, had seventy-eight registrants. These trips followed a different route, but met together in Victoria BC. C8 and C9 left Vancouver together for Prince Rupert by chartered steamer on 28 August, with a total of about forty registrants. C9 registrants left at Prince Rupert on a chartered train that took them up the Skeena valley. C8 registrants continued on to Juneau, Alaska by steamer, then returned to Skagway, and took the train to Whitehorse, whence they travelled by river steamer to Dawson in theYukon.

The ten Guide Books, covering twenty-seven Excursions, provided by far the best summary of the geology of Canada then available. They included a "Geological Map of the Dominion of Canada and Newfoundland," (at a scale of 100 miles to the inch) newly compiled by G. A. Young. They were much more detailed and complete than the first edition of the Geology and Economic Minerals of Canada that had been published by the GSC in 1909.

Among the "local" field excursions the most popular were: B3, led by W. A. Parks, H. V. Ellsworth, and Miss Alice Wilson (the only female geologists to participate actively in the Congress) to the Paleozoic near Hamilton; A7 led by F. D. Adams, J. A. Bancroft, Rev. Abbé Guimont and R. P. D. Graham to the Monteregian Hills; A3 led by Miller with six other guides to Sudbury, Cobalt and Porcupine (it included a newly compiled geological map of those parts of northern Ontario); A5 led by T. C Denis and J. A. Dresser to the asbestos mining region in the eastern townships of Quebec, southeast of Montreal; and A2 led by F. D. Adams and A. E. Barlow to the Grenville of the Halliburton-Bancroft region, north of Toronto. No doubt B1, the day-trip to Niagara was also popular (though there is no record of the attendance) as was B6, a visit to the Muskoka Lakes, with the emphasis on tourism rather than geology.

For those interested in the Quaternary there were four excursions: A4, led by A. P. Coleman and F. B. Taylor to examine the Iroquois beach and Niagara; A10 led by J. W. Goldthwait to Montreal, Covey Hill and Ottawa; and short excursions to explore the Scarborough bluffs (B2 led by A. P. Coleman), and the moraines north of Toronto (B5 led by F. B. Taylor). An interesting feature of the Niagara trips must surely have been the active participation of an uninvited guide, J. W. Spencer, who had written a major monograph on Niagara Falls, published by the GSC in 1907, but who was still promulgating interpretations that rejected major ice dams, and so differed considerably from those of the official leaders (Tinkler, 1994; Middleton, 2004).

Thirteen detailed field excursion guides were prepared by the GSC, and published together in ten Guide Books, all well illustrated and many of considerable length. To avoid confusion, note that in some cases the same excursion was offered both before and after the Congress (e.g., A3 and C6). Two excursions (by A. P. Coleman and F. B. Taylor) were prepared and republished by the Ontario Bureau of Mines (Report XXII, Part I: 238-255, 256-260), but are included in the ten GSC Guide Books. There is no doubt that the excursions were a great success, and many of the more eminent visiting geologists attended more than one. Considering that the first began on 13 July, and the last did not end until 5 October, the commitment of Canadian geologists to this part of the IGC was greater than that required by the formal sessions, by far. Part of one Field Guide is reproduced as an Appendix to this article.

The Compte-Rendu provided a summary of the Congress finances (p. ix). The total expenses were almost $\$ 59,000$, of which $40 \%$ was for excursions, and $30 \%$ was for the cost of organization. The Congress was supported by grants of $\$ 25,000$ from the Government of Canada, and grants ranging from $\$ 7,000$ to $\$ 1,661$ from four Provinces. Grants were also received from the Canadian Northern Railroad, and from several mining companies. Registration fees yielded a little less than $\$ 5,000$. But the Congress was, of course, heavily subsidized by those who spent countless hours in its organization, while supported financially by the GSC, Provincial surveys and universities.

\section{Summary}

The Toronto IGC was regarded in Canada as a great success, and published reviews were uniformally favourable. The summary provided by the GSC's official historian, Morris Zaslow (1975: 305) can scarcely be improved:

The meetings did much to bring Canadian geology and the Survey into the mainstream of world science. Eminent scientists from other lands were [able] to see Canada for themselves, to meet [Canadian geologists] and take the measure of their interests and abilities, and to form many strong, lasting friendships. . . . The visitors helped Canadians to understand their own geology better [and] in return carried away ideas that they could apply at home.... 
As regards the technical sessions, the Toronto IGC was probably no different from most others. The long years of planning, and the need to accommodate delegates with many different interests and from many different countries, means that such conferences cannot respond adequately to recent scientific advances. For that purpose, smaller, more focussed conferences are better.

\section{Publications}

McInnes, William, D. B. Dowling, and W. W. Leach, eds., 1913, The Coal Resources of the World : an inquiry made upon the initiative of the Executive Committee of the XII International Geological Congress, Canada, 1913, with the assistance of geological surveys and mining geologists of different countries. Toronto: Morang, 3 v., and an atlas of maps.

Congrès Géologique International, Compte-Rendu de la XIIE Session, Canada, 1913. Ottawa, Government Printers, 1034 pp.

Guide Book No. 1: Excursions in Eastern Quebec and the Maritime provinces (Excursion A1). Two volumes, 407 pp.

Guide Book No. 2: Excursions in the Eastern Townships of Quebec and the Eastern Part of Ontario (Excursions A2, A5, and A9), 142 pp.

Guide Book No. 3: Excursions in the Neighbourhood of Montreal and Ottawa (Excursions A6, A7, A8, A10, A11), 162 pp.

Guide Book No. 4: Excursions in Southwestern Ontario (Excursions A4, A12, B3), 140 pp.

Guide Book No. 5: Excursions in the Western Peninsula of Ontario and Manitoulin Island (Excursions B4, B7, B9 and C5), 107 pp.

Guide Book No. 6: Excursions in Vicinity of Toronto and to Muskoka and Madoc (Excursions B2, B5, B6, B8 and B10), 67 pp.

Guide Book No. 7: Excursions to Sudbury, Cobalt and Porcupine (Excursion A3 and C6), 150 pp. (with a geological map provided by the Ontario Bureau of Mines).

Guide Book No. 8: Transcontinental Excursion C1. Toronto to Victoria and return via Canadian Pacific and Canadian Northern Railways. Part I, pp. 13-101; Part II, pp. 111-274; Part III, pp. 280-386.

Guide Book No. 9: Transcontinental Excursion C2. Toronto to Victoria and return via Canadian Pacific, Grand Trunk Pacific and National Transcontinental Railways, 164 pp.

Guide Book No. 10: Excursions in Northern British Columbia and Yukon Territory and along the North Pacific Coast (Excursions C8 and C9), 176 pp.

\section{Acknowledgements}

I thank David Oldroyd for the invitation to prepare this article, and for his numerous comments on an early draft. Mike Easton kindly provided an Introduction to the Appendix. Brian Shipley, who has written a profile of Brock for the Dictionary of Canadian Biography, kindly sent me a pre-publication copy. Other readers who helped included: Ian Brookes, Andrew Miall, and Charles Smith.

\section{References and Sources}

Cook, R., ed., 1966-2007, Dictionary of Canadian Biography. Fifteen volumes now published by the University of Toronto Press. Available online at: http://www.biographi.ca.

Hofmann, H. J., 1982, J. W. Dawson and 19th century Precambrian paleontology: Third North American Paleontological Convention, Montreal, Proceedings, v. 1, pp. 243-249.

Langton, H. H., et al., 1906, The University of Toronto and its Colleges, 1827-1906. Toronto, University of Toronto Library.

Lewis, C., 2000, The Dating Game: One Man's Search for the Age of the Earth. Cambridge, Cambridge University Press.

Macqueen, R. W., ed., 2004, Proud Heritage: People and Progress in Early Canadian Geoscience. Geological Association of Canada, Geoscience Canada Reprint Series 8. (This publication includes original as well as reprinted articles.)
Middleton, G. V., 2004, J. W. Spencer (1851-1921): his life in Missouri and Georgia, and work on proglacial lakes. Geoscience Canada, v. 31, pp. $147-156$.

Middleton, G. V., 2005, Geologists elected fellows of the Royal Society of Canada, 1883-1932. Northeastern Geology \& Environmental Sciences, v. 27 , pp. $187-190$.

Middleton, G. V., 2006, Andrew Cooper Lawson (1861-1952): how a boy from Canada became a legendary professor of Geology at Berkeley: GSA Today, v. $16(4 / 5)$, pp. 50-51.

Morgan, H. J., compiler, 1912, The Canadian Men and Women of the Time. Toronto, William Briggs, second edition.

Tinkler, K. J., 1994, Déjà vu: the downfall of Niagara as a chronometer, 1845-1941, in H. J. Gaylor, ed., Niagara's Changing Landscapes, Ottawa, Carleton University Press, pp. 81-109.

Yochelson, E. L., 2001, Smithsonian Institution Secretary, Charles Doolittle Walcott. Kent (Ohio) and London, Kent State University Press.

Yoder, H. S., Jr, 1992, Norman L. Bowen (1887-1956), MIT class of 1912, first predoctoral fellow of the Geophysical Laboratory: Earth Sciences History, v. 11, pp. 45-55. Available at: http://vgp.agu.org/bowen_paper/ bowen_paper.html

Young, Davis A., 1998, N. L. Bowen and Crystallization-Differentiation: The Evolution of a Theory. Washington DC, Mineralogical Society of America.

Zaslow, M., 1975, Reading the Rocks: the Story of the Geological Survey of Canada 1842-1972. Toronto, Macmillan of Canada.

Zeller, Suzanne, 1987, Inventing Canada: Early Victorian Science and the Idea of a Transcontinental Nation. Toronto, University of Toronto Press.

The following are reviews of the Toronto Congress that were published at the time:

Anonymous, 1913, The Twelfth International Geological Congress: Canadian Mining Journal, v. 34, pp. 455-472, 504-517.

Hobson, Bernard, 1913, The Twelfth International Geological Congress in Canada: Geological Magazine, New Series (5), v. 10, pp. 486-490.

Penrose, R.A.F., Jr, 1913. The twelfth International Geological Congress: Franklin Institute Journal, v. 176, pp. 583-586.

P. D. Q. [Percy D. Quesnel], 1913, Geologkongressen i Kanada och des exkusioner: Geologiska Föreningens i Stockholm Förhandlingar, v. 35, pp. 398-402.

Steinmann, G., 1914, Vom internationalen Geologenkongress in Toronto: Geologische Rundschau, v. 5, pp. 215-218.

Termier, Pierre, 1913a, L'Excursion A1 du XIIe Congrès géologique international: la région appalachienne du Canada: Comptes Rendus Hebdomadaires des Séances de l'Académie des Sciences, tome 157, numero 16, pp 621-626.

Termier, Pierre, 1913b, L'Excursion C1 du XIIe Congrès géologique international: les terrains précambriens de la région des Lacs; les problèmes tectoniques des grandes chaînes de l'Ouest: Comptes Rendus Hebdomaires des Séances de l'Académie des Sciences, tome 157, numero 18, pp. 747-753.

R. C. W. [probably R. C. Wallace], 1913, The Twelfth International Geological Congress: Nature, v. 92 (1913-1914), 4 September, 1913, pp. 7-9. 